\title{
HUBUNGAN KOORDINASI MATA DAN TANGAN \\ DENGAN HASIL TANGKAPAN BOLA LAMBUNG \\ INFIELD, OUTFIELD PADA CABANG OLAHRAGA \\ SOFTBALL
}

\author{
Luby Tsani Ahwadi, Yunyun Yudiana, Nurlan Kusmaedi
}

Program Studi Ilmu keolahragaan

Departemen Pendidikan Kesehatan dan Rekreasi

Fakultas Pendidikan Olahraga dan Kesehatan

Universitas Pendidikan Indonesia, Jl. Dr. Setiabudhi No. 299 Bandung

Email: lubbytsani@student.upi.edu

\begin{abstract}
Abstrak
Olahraga Softball membutuhkan koordinasi mata dan tangan baik ketika pada waktu menyerang yaitu menghadapi lemparan bola pitcher dan pada saat bertahan yaitu saat menangkap hasil pukulan dari pemain lawan. Kemampuan bertahan yang dimaksud adalah ketika saat fielder menangkap hasil tangkapan bola lambung. Karena sangat penting dan vital dapat menentukan hasil pertandingan. Berhubungan dengan hal tersebut, tujuan dari penelitian untuk mengetahui hubungan koordinasi mata dan tangan dengan hasil tangkapan bola lambung posisi infield,untuk mengetahui hubungan koordinasi mata dan tangan dengan hasil tangkapan bola lambung posisi outfield, dan untuk mengetahui hubungan koordinasi mata dan tangan dengan hasil tangkapan bola lambung posisi infield dan outfield.pada cabang olahraga softball. Metode penelitian yang digunakan deskriptif korelasi dengan pengujian korelasi, teknik pengambilan sampel yang dilakukan yaitu sampling jenuh dengan jumlah sampel 14 orang atlet UKM Softball UPI. Hasilnya tidak terdapat pengaruh hubungan antara Koordinasi mata dan tangan dengan hasil tangkapan bola lambung infield outfield pada cabang olahraga softball dan nilai signifikansi yaitu0,824>0,05 yaitu 0,824 . Temuan penelitian terdapat hubungan yang negatif antara kedua variabel.
\end{abstract}

Kata kunci: Koordinasi mata dan tangan, hasil tangkapan bola lambung, Softball.

\section{PENDAHULUAN}

Berdasarkan data yang dikeluarkan Keberadaan olahraga softball di Bandung kurang cukup populer dibandingkan dengan sepak bola dan badminton yang sudah menjadi primadona dan memasyarakat. Karena mungkin banyak yang beranggapan bahwa olahraga ini diperuntukkan hanya untuk kalangan menengah ke atas, keterbatasan sarana dan prasarana, serta kurangnya sosialisasi mengenai cabang olahraga ini. Hal ini bisa dilihat dari perkembangan olahraga softball di kota Bandung sekarang. Di kota Bandung sendiri hanya terdapat kurang lebih hanya 10 klub yang ada. tetapi hal itu bukanlah salah satu penyebab utama, asalkan ada asa, 
kesungguhan, dan kecintaan tentunya hal tersebut bukan suatu halangan untuk berprestasi, bahkan hal tersebut dapat dijadikan suatu tantangan tersendiri.

Softball adalah suatu cabang olahraga yang memiliki makna dan filosofi hidup. Didalamnya terdapat unsur kerja sama, kerja keras, tekad, Kepercayaan tim satu sama lain, dan keberanian. Hal ini bisa dilihat dari permainan dimainkan oleh 9 orang yang membutuhkan kerja sama dan kepercayaan satu sama lain dan terlihat juga dari cara latihanya yang melahirkan tekad kerja keras dan keberanian.

Dari beberapa teknik dasar kemampuan teknik menangkap merupakan salah satu kemampuan yang sangat penting dalam perrmainan, karena kemampuan tersebut hal yang sangat berpengaruh dalam permainan softball.Seperti yang di jelaskan oleh (dalam Soeprapto, 1979, hlm.7274)Beberapa macam teknik menangkap bola dibagi menjadi tiga macam yaitu: Teknik menangkap bola guling tanah (ground ball),Teknik menangkap bola melambung (Fly ball), dan Teknik menangkap bola lurus (straight ball).

Kemampuan menangkap bola lambung merupakan hal yang sangat penting Pada saat regu mendapat giliran bertahan karena hal ini dapat menjadi faktor penentu pertandingan, Dalam hal ini tentunya kemampuan teknik tersebut harus sering dilatih supaya dapat menjadi suatu otomatisasi gerak dan mencegah terjadinya kesalahan error saat pertandingan, hal ini mengacu pada penjelasan yang dikemukakan oleh ( Suharno HP,1986:62) yaitu adapun tujuan melatih teknik adalah untuk mengotomatisasi gerakan sesuai dengan teknik gerakan yang dikehendaki dan benar otomatisasinya.
Dan berkesinambungan dengan penjelasan yang dikemukakan oleh Luxbachter (dalam Iman Imanudin 2014. hlm, 64) yaitu teknik dasar ialah semua gerakan yang mendasari permainan,dan dengan modal tersebut seseorang dapat bermaindengan atau berlatih secara terarah. Selain kemampuan teknik dasar menangkap bola lambung tentunya harus disertai dengan kemampuan Koordinasi matatangan yang bagus. Koordinasi mata tangan memiliki andil yang cukup besar terhadap penguasaan keterampilan bermain softball khususnya pada keterampilan menangkap bola lambung. Hal ini mengacu pada penjelasan yang dikemukakan oleh (Bompa 2004:44) yaitu Semakin tinggi tingkat koordinasi seseorang semakin mudah untuk mempelajari teknik dan taktik yang baru maupun yang rumit.

Koordinasi mata tangan merupakan bagian dari kemampuan biomotor yang dimilikisetiap pemain. Dalam hal ini peran seorang pelatih sangat penting untuk menerapkan dalam program latihanya karena olahraga softball ini. Dimana Pelatih diharapkan mampu merencanakan program latihan yang disesuaikan dengan kondisi pemain, tempat, maupun kondisi lain yang dapat mempengaruhi latihan.

Diharapkan pada saat dilapangan seharusnya pemain dapat menangkap bola lambung dengan baik,tepat dan cepat sehingga dapat membuat mati pemain lawan tetapi bahkan atlet sekelas dunia pun gagal dan tidak tertangkap.Ini menjadi suatu hal yang kontradiktif seharusnya fungsi pelatih sebagai perancang dan pembuat program diharapkan lebih kreatif dan dinamis, misalnya, dalam melatih biasanya mereka tidak mempertimbangkan koordinasi mata tangan yang dimiliki oleh pemain, sehingga perlakuan biasanya 
disamakan antara yang memiliki kemampuan koordinasi mata tangan tinggi dan kemampuan koordinasi mata tangan rendah. (Sri Santoso Sabarini, 2008, Hlm.22).

Oleh karena itu berdasarkan penjelasan diatas peneliti ingin tertarik untuk meneliti "Hubungan Koordinasi Mata Dan Tangan Dengan Hasil Tangkapan Bola Lambung Infield Outfield Pada Cabang Olahraga Softball”

\section{METODE}

Metode penelitian kuantitatif korelasi dimana penelitian korelasi bertujan untuk mengidentifikasi hubungan prediktif dengan menggunakan teknik korelasi. Penelitian korelasi melibatkan pengumpulan data untuk menentukan apakah, dan untuk tingkat apa terdapat hubungan dua atau lebih variabel yang dapat dikuantitatifkan. Serta tujuan studi korelasi juga untuk menentukan hubungan antara variabel, atau untuk menggunkan hubungan tersebut untuk membuat prediksi, (Gay, 1981:193) dalam Emzir (2009, hlm 38).

Populasi merupakan suatu tempat untuk pengambilan data, dengan adanya populasi sebuah data dapat diambil dan dapat dianalisi, oleh karenanya populasi merupakan suatu hal yang sangat penting sekali untuk terlaksananya penelitian.

Oleh karenanya Sugiyono (2012, hlm 119) menuturkan populasi merupakan suatu wilayah generalisasi yang terdiri atas : obyek/subyek yang mempunyai kualitas dan karakteristik tertentu yang ditempatkan oleh peneliti untuk dipelajari dan kemudian ditarik kesimpulan.

Berhubungan dengan penjelasan tersebut maka yang menjadi populasi dalam penelitian ini yaitu atlet UKM softball UPI berjumlah sebanyak 14 orang.

Sampel menurut Sugiyono (2012, hlm.81) adalah bagian dari jumlah dan karakteristik yang dimiliki oleh populasi tersebut. Teknik pegambilan sampel yang digunakan adalah Non-Probalility Sampling ialah teknik sampling yang tidak memberikan kesempatan (peluang) pada setiap anggota populasi untuk dijadikan anggota sampel. Sehingga penulis mengambil teknik sampling jenuh karena populasi kurang dari 100 .

Dalam penelitian ini menggunkan teknik Non Probability sampling dimana pengunaan teknik pengambilan sampel tidak memberikan peluang/kesempatan sama bagi setiap unsur atau anggota populasi untuk dipilih menjadi sampel. Dalam penelitian ini teknik pengambilan sampel yang dilakukana yaitu sampling jenuh yaitu penentuan sampel dengan menjadikan semua sampel dari total populasi, hal ini karena jumlah sampel populasi relatif kecil dan kurang dari 30 orang. Sehingga penelitian ini jumlah pengambilan sampel yang dilakukan 20 orang dari atlet UKM softball UPI.

Instrumen penelitian yang digunakan dalam penelitian ini adalah Tes Speed Coordination Time ini merupakan salah satu alat untuk mengukur koordinasi gerak tubuh, terutama koordinasi mata, tangan, dan kaki. Alat ini memberikan stimulus melalui visual atau pandangan berupa tiga warna lampu yang berbeda. Alat ini merekam waktu koordinasi gerak tubuh.Dan menggunakan instrument Test O'Donell Fielding fly ball. Tes yang digunakan dalam pengukuran keterampilan menangkap bola lambung.Tes ini diciptakan oleh O'Donell dalam (Nurhasan2007 hlm 243), dan instrument 
ini memiliki nilai validitas 0,78 dan reliabilitas 0,83. Deskripsi dari tes ini adalahsubjek berdiri dibelakang garis yang dibuat 1,81 meter dari dinding sambil memegang bola ketika memulai aba-aba ya bola dilemparkan ke dinding diatas garis batas yang dibuat setinggi $3,86 \mathrm{~m}$ kesempatan satu kali diberi waktu 30 detik untuk melempar ke bidang sasaran dan menangkapnya boleh didepan garis

Analisis data atau pengolahan data merupakan salah satu langkah yang penting dalam melakukan penelitian, karena pengolahan data ini akan berhubungan dengan pengambilan keputusan atau penarikan kesimpulan. Oleh sebab itu data yang ddiambil dan penghitungan data haruslah valid. Supaya tingkat signifikansi sesuai dengan hipotesis awal. Penghitungan data ini dilakukan dengan menggunakan bantuan dari program Software Statistical Product And Service Solution (SPSS). Program ini memiliki kemampuan menganalisis cukup tinggi. Kemudian untuk menganalisis data memiliki beberapa tahap yaitu pertama melakukan uji normalitas data yang bertujuan untuk melihat data berdistribusi normal atau tidak. Dengan nilai signifikansi atau nilai probalilitas $<0,05$ maka data tidak berdistribusi normal dan jika data >0,05 maka data berditribusi normal.Kemudian katakanlah data berdistribusi normal sehingga analisis uji parametrik menggunakan rumus Koefisien Korelasi Product Moment/Bivariate, dan apabila data tidak berdistribusi normal, maka dilakukan analisis uji non-parametrik., kemudian setelah mendapatkan hasil maka dilakukan uji korelasi. Jika sebuah terdapat hubungan antara kedua variabel, maka selanjutnya dilakukan uji korelasi Product Moment pearson/Bivariate digunakan untuk mengetahui hubungan yang positif dan signifikan.

\section{HASIL DAN PEMBAHASAN}

Dapat diketahui data pemain Infield dan Outfield nilai minimum sebesar 0,52 dan nilai maximum sebesar 0,36 dan sebesar 0,44 merupakan nilai mean untuk tes Speed Coordination Reaction Time posisi infield,outfield dan nilai Std deviation sebesar 0,515. Kemudian untuk Fielding Fly Ball infield nilai minimum sebesar 11 dan nilai maximum sebesar 18 dan mean sebesar 15,21 sedangkan Std deviation sebesar 2,045.

Peneliitian ini untuk mengetahui suatu hubungan antara koordinasi mata dan tangan dengan hasil tangkapan bola lambung infield outfield pada cabang olahraga softball. Setelah dilakukan penelitian, pengolahan dan analisis data, berdasarkan hasil yang telah diperoleh maka peneliti menemukan temuan. Untuk hasil nilai tertinggi tes speed coordination reaction time atlet UKM Softball UPI adalah 0,36 , sedangkan hasil nilai terendah adalah 0,44 dan nilai rata-rata sebesar 0,44. Untuk nilai hasil tangkapan bola lambung didapatkan hasil nilai tertinggi yaitu 18 , sedangkan nilai terendah adalah 11 , dan nilai rata-rata sebesar 15,21 . Hasil anailsis data ini membuktikan bahwa tidak terdapat hubungan yang signifikan antara koordinasi mata tangan dengan hasil tangkapan bola lambung infield,outfield pada cabang olahraga softball. Hal ini disebabkan karena kecepatan koordinasi mata dan tangan yang disebabkan oleh sensor lampu yang harus disesuaikan dengan anggota tubuh seperti tangan dan kaki yang ada di alat speed coordination reaction time, Makin cepat atau sesuai dengan bagian sensor lampu 
yang akan semakin baik waktu reaksinya.

Dimana waktu reaksi dimulai dari stimulus yang melibatkan panca indera (tangan, mata, kaki).Perpindahan rangsangan dari urat saraf eferen ke sistem syaraf pusat dan menghasilkan tanda isyarat yang akan dikirim kepada efektor, rangsangan isyarat ini pada otot skeletal menimbulkan kontraksi, gerakan, aktivitas fisik atau kerja menurut Harsono dalam Hanafi (2010. hlm,7).Hal ini membuktikan bahwa ada unsur gerakan yang harmonis dalam tubuh yaitu antara kerja syaraf pusat sebagai penampung reseptor dan diteruskan melalui efektor. Hal ini didukung oleh :

Penelitian Sridadi, M.Pd softball Dosen Prodi PJKR FIK UNY(2007.hlm 9) mengenai Sumbangan tes koordinasi mata, tangan, dan kaki yang digunakan untuk seleksi calon mahasiswa baru Prodi PJKR terhadap mata kuliah praktek dasar gerak softball. Menjelaskan dalam penelitiannya bahwa sumbangan tes koordinasi mata tangan memiliki sumbangan sebesar 44,9\% atau $45 \%$ untuk seleksi calon mahasiswa baru Prodi PJKR terhadap mata kuliah praktek.

Dan ada pun penelitian yang dilakukan Oleh Sri Santoso Sabarini Program studi ilmu keolahragaan Program pasca sarjana Universitas sebelas maret Surakarta (2008.hlm 10) Perbedaan Pengaruh Latihan Dan Koordinasi Mata Tangan Terhadap Keterampilan Bermain Baseball menjelaskan bahwa

Kelompok pemain yang mendapat metode latihan dengan weight training dan Plyometric dibandingkan, maka dapat diketahui bahwa kelompok perlakuan dengan Plyometric memiliki peningkatan keterampilan bermain baseball sebesar 12.90 yang lebih baik dari pada kelompok metode latihan dengan weight training. antara kelompok pemain yang memiliki koordinasi mata-tangan tinggi dan rendah dibandingkan, maka dapat diketahui bahwa kelompok pemain yang memiliki koordinasi mata-tangan tinggi memiliki peningkatan keterampilan bermain baseball sebesar 11.10 yang lebih baik dari pada kelompok pemain yang memiliki koordinasi mata-tangan rendah.

Maka jika dilihat dari kedua penelitian tersebut dapat diartikan bahwa suatu kioordinasi mata dan tangan dapat meningkat atau dipengaruhi oleh faktor latihan yang terprogram. Sehingga koordianasi dapat dipengaruhi oleh waktu reaksi jika sering dilatih akan menjadi bersifat automatisasi, seolah-olah sudah menjadi kebiasaan.

Selain itu ada beberapa faktor yang dapat memepengaruhi reaksi, yang dijelaskan dalam Permatasari (2015, hlm 11) bahwa Easingwood, G (2010) mengungkapkan bahwa faktor yang mempengaruhi waktu reaksi ada 8 faktor diantaranya:

1) Konsentrasi mempengaruhi waktu reaksi, dan ini juga termasuk ketegangan otot.

2) Relevansi stimulus bagi kelangsungan hidup juga mempengaruhi waktu reaksi, situasi yang berpotensi mengancam nyawa lebih mungkin untuk mendapatkan respon yang cepat.

3) Usia merupakan faktor yang mempengaruhi waktu reaksi, umumnya meningkat dari lahir sampai sekitar akhir dua puluhan. Kemudian menurun perlahan. Penurunan waktu reaksi meningkat sebagai seseorang mencapai tahun ketujuh puluh mereka dan seterusnya.

4) Stimulus visual apakah itu terlihat secara langsung. 
5) Mempraktekkan atau mengulangi respon meningkatkan waktu reaksi, misalnya olahraga orang berlatih untuk olahraga yang mereka pilih.

6) Kelelahan, kelelahan mental termasuk kurang tidur.

7) Gangguan seperti stimulus sensorik lainnya seperti kebisingan latar belakang.

8) Kebugaran fisik memiliki efek langsung pada waktu reaksi.

Dalam hal diatas menunjukkan bahwa betapa banyak fakto yang yang mempengaruhi waktu reaksi individu yang keberadaanya sangat berkaitan dengan koordinasi.

Namun ada beberapa faktor limitasi juga yang menyebabkan data ini menjadi bias, diantaranya: Ukuran sampel kecil relatif terbatas, karena sampel yang digunakan kurang dari 30 orang, hal ini menyebabkan suatu hubungan yang tidak signifikan.

Dalam hal ini kurang tepatnya waktu pengukuran, karena waktu pengukuran yang dilakukan ketika kondisi individu lagi keadaan normal.

\section{KESIMPULAN}

Berdasarkan analisis data hasil, pengujian hipotesis dan pembahasan pada bab sebelumnya antara koordinasi mata dan tangan dengan hasil tangkapan bola lambung infield outfield pada cabang olahraga softball, maka kesimpulan dalam penelitian ini adalah sebagi berikut: (1) Tidak terdapat hubungan antara koordinasi mata dan tangan dengan hasil tangkapan bola lambung pada posisi infield; (2) Terdapat hubunganantara koordinasi mata dan tangan dengan hasil tangkapan bola lambung pada posisi outfied. (3) Tidak terdapat hubungan yang positif antara koordinasi mata dan tangan dengan hasil tangkapan bola lambung infield,outfield pada cabang olahraga softball.

Hasil penelitian menunjukkan hubungan antara koordinasi mata dan tangan dengan hasil tangkapan bola lambung infield,outfield pada cabang olahraga softball tidak memiliki hubungan dan memberikan kontribusi yang signifikan. Namun, hal ini bukan berarti koordinasi mata dan tangan dengan hasil tangkapan bola lambung tidak diperlukan, tetapi justru sebaliknya koordinasi mata dan tangan diperlukan sekali bagi setiap pemain softball,sedangkan hasil tangkapan bola lambung bermanfaat untuk menambah keterampilan pemain softball dalam pada saat posisi bertahan

Rekomendasi didasarkan pada hasil empirik analisis data, pengujian hipotesis dan kesimpulan yang telah diuraikan, rekomendasi ditujukan kebepada peniliti dan pada pelaku olahraga,dan pada lembaga studi sebagi berikut, Diharapakan penelitian ini dapat memberikan informasi penting dan bermanfaat bagi pelaku olahraga, khususnya cabang olahraga softball. Diharapakan untuk penelitian selanjutnya banyak lagi penelitianpenelitian mengenai olahraga softball, sehingga banyak memperkaya wawasan dan keilmuan bagi insan softball dan membuktikan bahwa olahraga softball sudah terukur dan pasti. 


\section{DAFTAR PUSTAKA}

Adang Suherman \& Nur Indri Rahayu, (2014). Modul Statistika Untuk Ilmu Keolahragaan. Bandung: FPOK UPI.

Ajang,Suparlan,dkk. 2008. Pembelajaran Softball. Bandung.: FPOK UPI Bandung.

Arikunto, S. (2010). ProsedurPenelitian (Suatu Pendekatan Praktik).Jakarta: Rineka Cipta.

Arikunto, Suharsimi, (2006). ProsedurPenelitian Suatu Pendekatan Praktik. Jakarta: Rineka Cipta.

Bompa, Tudor O.(2004) Theory and Methodology of Training to Key Athletic Performance.Canada:

. Kendal: Hunt Publishing Company

Darmadi, H. (2013). Metode Penelitian Pendidikan Sosial. Bandung: Afabeta.

Edi, W. (2010). Olahraga Menggunakan Bola Kecil. Bogor: Quadra.

Emzir. 2009. Metodologi Penelitian Pendidikan. Jakarta. Pt Raja Grafindo Persada.

George,Sullivan .1992. Teknik Bermain Baseball. Bandung: CV Pionir Jaya Bandung

Green, Andrew (2013). The biomechanical and physiological predictors of golf drive performance, before and after a hole-to-hole distance walk. University of the Witwatersrand, Faculty of Health Sciences. (Thesis)

Hanafi, Suriah. 2010. Efektifitas Latihan Beban Dan Latihan Pliometrik Dalam Meningkatkan Kekuatan Otot Tungkai Dan Kecepatan Reaksi.(Jurnal). Semarang. Universitas Negeri Makassar

Herna,Megawati. 2013. Pengaruh Model Pembelajaran Dan Kepercayaan Diri Terhadap Hasil Belajar Pitching (Studi Eksperimen pada UKM Softball UPI Bandung. Program Studi Pendidikan Jasmani Kesehatan dan Rekreasi FPOK UPI.(Jurnal)

Ichsani, 2012. Kontribusi Kekuatan Otot Lengan dan Koordinasi Mata Tangan Terhadap Kemampuan Memukul Bola Pada Permainan Kasti murid SD Negeri 164 Taipa Kabupaten Takalar. Program Studi Ilmu Keolahragaan FIK Universitas Negeri Makassar (Jurnal).

International Softball Federation. 2002. Official Rules of Softball.

Iqbal,Nurhuda. 2013. Kontribusi Power Lengan Dan Fleksibilitas Panggul Terhadap Hasil Pukulan Dalam Cabang Olahraga Softball. Program Studi Pendidikan Kepelatihan Olahragai FPOK UPI.(Jurnal)

Nurhasan dan Hasanudin. (2007). Modul Tes dan Pengukuran Keolahragaan. Bandung: Red Point. Nurhasan dan Hasanudin. (2014). Modul Tes dan Pengukuran Keolahragaan. Bandung: Red Point. Parno. (1992) Olahraga Pilihan Softball. Jakarta: Departemen Pendidikan dan Kebudayaan Direktorat Jendral Pendidikan Tinggi Proyek Pembinaan Tenaga Kependidikan.

Permatasari Nita KN. 2015. Pengembangan Alat Ukur Waktu Reaksi Tangan Berbasis Microcontroller. (Skripsi). Bandung. Universitas Pendidikan Indonesia

Sianipar T. 2007. Metodologi Penelitian Kuantitatif dan Kualitatif Konsep,Prinsip dan Aplikasi. Jakarta. Universitas Negeri Jakarta

Sridadi. 2007. Sumbangan Tes Koordinasi Mata Tangan dan Kaki Yang Digunakan Untuk Seleksi Calon Mahasiswa Baru Prodi PJKR Terhadap Mata Kuliah Praktek Dasar Gerak Softball. (tesis). Universitas Yogykarta.

Sri,Santosa Sabarini. 2008.Perbedaan Pengaruh Latihan Dan Koordinasi Mata Tangan Terhadap Keterampilan Bermain Baseball. (Tesis). Universitas Surakarta

Soeprapto.(1979).Modul Pembelajaran Olahraga Softball.Jakarta: Departemen Pendidikan dan Kebudayaan Direktorat Jendral Pendidikan Tinggi Proyek Pembinaan Tenaga Kependidikan.

Soleh Hartadi. 2007. Kontribusi Kekuatan Otot Lengan dan Koordinasi Mata Tangan dengan Ketepatan Servis Atlet Bolavoli Yunior di Klub Bolavoli Yuso Yogyakarta. (Skripsi).

SuharnoHP. (1982). Ilmu CoachingUmum (diktat).Yogyakarta: IKIPYogyakarta.

Sugiyono. (2014). Metodologi Penelitian Kuantitatif dan Kualitatif Konsep. Bandung: Alfabeta. 